\title{
O estágio em perspectiva semiótica: uma experiência mediada por imagens em um curso de licenciatura em educação física
}

DIEGO DE SOUSA MENDES

Universidade Federal de São João del-Rei, São João del-Rei, MG, Brasil

MAURO BETTI

Universidade Estadual Paulista “Júlio de Mesquita Filho", Bauru, SP, Brasil

RESUMO

O estudo investigou quais repercussões decorreram da constituição do estágio supervisionado a partir de pressupostos da semiótica de Charles S. Peirce. Na dinâmica de uma pesquisa-ação, realizada com uma turma de estágio supervisionado em educação física, da Universidade Federal de São João del-Rei (UFSJ), enfatizamos um enfoque pedagógico que privilegiou a comunicação, o uso da produção e da socialização de imagens fotográficas e de vídeos produzidos pelos participantes do estudo, como meios de potencializar a experiência formativa nos estágios. A análise dos dados demonstrou que o processo de explorar as imagens fotográficas e o audiovisual como meios detonadores de reflexão coletiva e do ímpeto de investigação sobre as práticas pedagógicas impactou a conduta docente dos participantes do estudo, tornando a experiência de estágio mais significativa em potencializar os diálogos e as reflexões que envolvem os participantes do estudo.

\section{PALAVRAS-CHAVE}

estágio supervisionado em educação física; semiótica; tecnologias digitais de informação e comunicação (TDIC). 
INTERNSHIPS FROM A SEMIOTIC PERSPECTIVE:

AN EXPERIENCE MEDIATED THROUGH IMAGES

IN A IN PHYSICAL EDUCATION TEACHING COURSE

\begin{abstract}
This study investigated the consequences that arose from the implementation of a supervised internship based on Charles S. Peirce's assumptions of semiotics. Using an action research methodology with a supervised internship class in the Department of Physical Education at the Federal University of São João del-Rei (UFSJ), we emphasize a pedagogical approach that privileges communication - the production and socialization of photographic images and videos produced by the participants - as a way to strengthen formative experiences during the internships. The data analysis showed that the process of exploring the photographic and audiovisual images as mediums to express collective reflection and research impetus on pedagogical practices, impacted the study participants' teaching conduct, making the internship experience more meaningful and enhancing dialogues and discussions between study participants.
\end{abstract}

\title{
KEYWORDS
}

supervised internship in physical education; semiotics; digital information and communication technologies (TDIC).

\section{LA PASANTÍA EN PERSPECTIVA SEMIÓTICA: UNA EXPERIENCIA MEDIADA POR IMÁGENES EN UN CURSO DE LICENCIATURA EN EDUCACIÓN FÍSICA}

\section{RESUMEN}

El estudio investigó cuáles consecuencias resultaron del establecimiento del pasantía supervisada a partir de las presuposiciones de la semiótica de Charles S.Peirce. Utilizando la metodología de investigación-acción, realizada con un grupo de pasantía supervisada en educación física, de la Universidad Federal de Sao João del-Rei (UFSJ), enfatizamos en un enfoque pedagógico que favorece la comunicación, la producción y la socialización de las imágenes fotográficas y videos producidos por los participantes, como un medio para mejorar la formación en las capacitaciones. El análisis de los datos mostró que el proceso de explorar las imágenes fotográficas y las audiovisuales como medio detonadores de la reflexión colectiva y el impulso de investigación sobre las prácticas pedagógicas ha impactado en la conducta docente de los participantes, haciendo la experiencia en la pasantía más significativa en potenciar los diálogos y las discusiones entre los participantes.

\section{PALABRAS CLAVE}

pasantía supervisada en educación física; semiótica; tecnologías digitales de información y comunicación (TDIC). 


\section{INTRODUÇÃO}

O presente trabalho partiu de um diagnóstico de que as experiências de estágio supervisionado nos cursos de licenciatura, muitas vezes, são meramente descritivas, informativas, burocráticas e baseadas em relatos verbais, orais e escritos, distante das demandas por uma formação crítica, reflexiva e criativa para os futuros professores. Além disso, nos incomodava o distanciamento que os estágios supervisionados mantinham das práticas comunicativas contemporâneas, em que a predominância da imagem e das tecnologias digitais de informação e comunicação (TDIC) se faz sentir.

Desse modo, pareceu-nos necessário um investimento na temática das possibilidades formativas do estágio supervisionado em educação física, concebendo-o em uma perspectiva comunicativa, em que as mais variadas linguagens e os diversos meios de comunicação (incluindo-se aí especialmente as TDIC) poderiam ser considerados conteúdos e meios a uma só vez, sem dissociação, visando a uma formação mais criativa (dimensão estética), cidadã (dimensão ética) e crítica (dimensão lógica/ científica) dos professores em formação inicial (PEFIs) ${ }^{1}$.

Reconhecíamos, assim, que uma aula sempre está a comunicar algo, e que tal elemento comunicativo se encontra no cerne dos processos reflexivos reivindicados desde a década de 1990 para a formação de professores no Brasil (Nóvoa, 1995; Pimenta e Ghedin, 2006) - embora a literatura especializada sobre tal temática jamais tenha explicitado ou mesmo se aprofundado sobre essa questão. Sendo assim, nos questionávamos como provocar o olhar dos PEFIs durante os estágios para o que uma aula está a comunicar? Como desenvolver um olhar aguçado para a prática pedagógica, reconhecida por nós como uma interlocução pedagógica ${ }^{2}$, e todas as nuances que ela carrega durante os estágios?

Com base em questões como essas, passamos a considerar que uma perspectiva semiótica de estágio, considerando-se aqui especificamente a semiótica desenvolvida por Charles S. Peirce ${ }^{3}$ e reconhecida como a lógica geral dos signos e de todas as linguagens, teria muito a oferecer em termos epistemológicos e meto-

1 Utilizamos a expressão "professores em formação inicial” (PEFIs) em vez de "estagiários" por considerar que nos estágios supervisionados de licenciaturas muitas vezes esses estudantes assumem funções proativas nas escolas, como a regência de turmas, a participação nos conselhos de classe, entre outras que não seriam funções de um mero estagiário, em uma concepção comum.

2 A expressão "interlocução pedagógica” foi adotada neste trabalho em oposição à ideia de intervenção (termo mais frequente no linguajar acadêmico). Entende-se aqui, conforme sugere Betti (2006), que o termo intervenção carrega, na prática pedagógica, uma conotação autoritária e distante de uma proposição dialógica e colaborativa de prática educativa.

3 Charles Sanders Peirce (1839-1914), lógico, matemático, físico, químico e filósofo norte-americano, foi um dos mais profícuos pensadores do século XX e pai da semiótica geral, deixando contribuições em múltiplas áreas, como: lógica, semiótica, astronomia, geodésia, matemática, teoria e história da ciência, teoria das linguagens, econometria, psicologia, entre outras. Disponível em: <https://estudospeirceanos.wordpress.com/cs-peirce/>. Acesso em: 15 out. 2016. 
dológicos aos estágios, em especial se correlacionada ao uso de registros fotográficos e/ou de audiovisuais das experiências dos estágios. Isso porque nos parece plausível que os registros fotográficos e/ou audiovisuais (tomadas como formas de linguagens) das experiências de estágios, bem como a socialização e a interpretação coletiva dessas imagens, apontam para novas e diversificadas possibilidades de reflexão e ressignificação das interlocuções pedagógicas dos PEFIs — posto que os registros dos estágios, tradicionalmente e na maior parte dos casos, costumam ocorrer tão somente por meio da linguagem verbal (oral e/ou escrita).

As potencialidades comunicativas das fotos e dos vídeos no contemporâneo se tornaram ainda mais proeminentes no contexto da comunicação em rede, especialmente no espaço dos sites de redes sociais, uma vez que esses ambientes se tornaram lugares de diálogo e compartilhamento de todo tipo de material (textos, imagens, sons) entre seus participantes. No que se refere aos estágios, conceber esse componente curricular em interlocução com esse novo contexto comunicativo pode significar a promoção de uma experiência de estágio mais conectiva entre seus agentes (supervisores, professores, PEFIs, estudantes da educação básica), no sentido de que essas ferramentas podem promover maior interação entre os diferentes sujeitos envolvidos nos estágios.

Assim, tomamos como hipótese que uma perspectiva semiótica de estágio supervisionado, aliada ao uso da produção e à socialização de imagens fotográficas e/ou audiovisuais, pode sinalizar novos olhares e perspectivas para o âmbito da formação de professores. Afinal, de que modo a lógica dos signos imagéticos (fotográficos e audiovisuais), agora unida à lógica da comunicação em rede nas redes sociais da internet - , pode auxiliar os professores a se confrontarem com suas crenças pedagógicas ou confrontá-las com os amplos e distintos modos de significação que emanam da linguagem visual durante a experiência de estágio?

\section{MÉTODO}

Para a realização deste estudo, utilizamos como referência metodológica os fundamentos da investigação-ação ou pesquisa-ação desenvolvidos por Stenhouse (1993) e Elliot (1993; 1998). Para esses autores, a premissa fundamental da pesquisa-ação é de que a ação educativa possa ser tomada como hipotética e experimental, verificando sua validade na prática diária, e que a investigação possa ser realizada pelos professores. Para tal, os professores devem assumir também a identidade de pesquisadores e, como tal:

1. oferecer hipóteses possíveis de serem verificadas em aula; e

2. oferecer descrições de casos ricos em detalhes, de modo a proporcionar um contexto comparativo com os próprios casos.

Assim, são características relevantes da pesquisa-ação: pressupor uma pesquisa participativa/colaborativa; orientar-se para processos formativos; ser uma estratégia associada à formação das pessoas envolvidas; centrar-se em atuações históricas e situações sociais que são percebidas pelos professores como problemáticas e passíveis de mudanças; buscar compreender o que está ocorrendo a partir da 
perspectiva dos implicados no processo; reelaborar discursivamente as contingências da situação e estabelecer as inter-relações entre elas; organizar seu desenvolvimento a partir de espirais cíclicas de reflexão-ação (Elliot, 1993; Tripp, 2005; Franco, 2005).

Seguindo tais preceitos, nossa pesquisa foi realizada junto ao curso de licenciatura em educação física da Universidade Federal de São João del-Rei (UFSJ), no componente curricular Estágio Supervisionado III, durante o primeiro semestre letivo de 2015, entre os meses de março e julho. Os sujeitos colaboradores da pesquisa foram todos os 30 acadêmicos matriculados (PEFIs) nesse componente curricular. Foram realizados, ao longo do semestre letivo, 18 encontros semanais na universidade com os PEFI, com duração de 1 hora e 50 minutos. Além disso, os PEFIs passaram 64 horas nos campos escolares realizando seus estágios entre os meses de março e junho de 2015.

Para realizar o campo escolar de estágio, os PEFIs foram organizados em oito grupos, sendo seis quartetos e dois trios. Esses grupos foram encaminhados para quatro escolas da cidade, sendo três unidades pertencentes à rede pública estadual e uma escola, à rede particular.

Os dados gerados na pesquisa foram captados por meio de:

1. registros em vídeo, gravações de áudios e em diário de campo elaborado pelo professor-pesquisador, em parceria com um observador externo, de todas as aulas e atividades realizadas durante o semestre letivo;

2. realização de grupos de discussão com os PEFIs; e

3. análise documental dos trabalhos produzidos pelos PEFIs durante a realização do estágio.

Os grupos de discussão foram organizados seguindo as recomendações normalmente atribuídas às dinâmicas de grupos focais, em que se sugere que esses sejam constituídos por um número mínimo de $5 \mathrm{a} 6$ participantes e máximo de 10 a 12 pessoas (Morgan, 1997), contendo 1 moderador e ao menos 1 observador externo, responsável por fazer anotações gerais sobre o desenvolvimento do grupo. Foram constituídos quatro grupos de discussões, dois deles realizados no início do semestre letivo e outros dois formados ao final do semestre. Todos os encontros realizados pelos quatro grupos foram filmados e posteriormente seu conteúdo foi transcrito, para análise.

Já as produções textuais e imagéticas, produzidas pelos PEFIs e compartilhadas nas aulas, foram analisadas de um ponto de vista semiótico. No que diz respeito às imagens (fotos ou vídeos dos estágios), esses documentos foram considerados no estudo como textos narrativos com significações (Kossoy, 2001) sobre as experiências escolares dos PEFIs. Desse modo, as fotos e os vídeos serviram para identificar os assuntos/temas que foram focados em determinado momento pelos estudantes, pois consideramos que a decisão de registro e de fixação de certo dado, em certo contexto específico, é uma opção do autor da imagem e revela um ponto de vista, uma intenção. Portanto, contém significados explícitos e latentes.

O tratamento dos dados foi realizado a partir de uma perspectiva qualitativa e em consonância com os aspectos interpretativos da semiótica peirceana. Nessa perspectiva, a interpretação está encerrada no campo dos efeitos que os signos produzem no campo lógico, no âmbito dos argumentos, da interpretação e da reflexão 
sobre o que os signos e os objetos do mundo expressam em termos de significação. Assim, engloba o ato ou a atitude de interpretar a experiência, considerando que interpretar é um ato contínuo que está presente na compreensão dos fenômenos, mas que também sucede a compreensão.

A interpretação, em sentido semiótico, considera primeiramente que o pesquisador deve abrir-se ao fenômeno para contemplá-lo, no sentido de estar/tornar-se disponível ao que o mundo empírico provoca em nossos sentidos e abstrações, auscultando os fenômenos. O segundo momento considera o olhar observacional, analítico, discriminatório. É o que Santaella (2001) trata como modo particular de observar os signos se corporificarem, revelarem suas características existenciais, separando o que é secundário do que é essencial ao problema de pesquisa, para se investir na compreensão do material que se relaciona ao tema/fenômeno estudado. Esse é um momento de "impregnação" ou "saturação", movimento de leitura e releitura incessante do material empírico, de modo a com ele estabelecer familiaridade, intimidade. $\mathrm{O}$ passo seguinte consiste na capacidade de generalização, ou seja, exercitar a atividade de extrair de um fenômeno particular aquilo que compõe uma classe geral. Aqui é possível construir a tipificação do material, ou seja, fazer a transição entre a empiria e a elaboração teórica.

Por fim, foi realizada uma triangulação entre os registros do diário de campo com as informações presentes nos grupos de discussão, assegurando que esses dados fossem confrontados e mais bem compreendidos.

Em relação aos cuidados éticos, foi solicitada autorização, por meio do Termo de Compromisso Livre e Esclarecido, aos PEFIs e aos pais dos alunos de ensino médio, para participação no estudo. Além disso, os estudantes do ensino médio assinaram um Termo de Assentimento, em que registravam seu interesse e permissão para participar do estudo. Quanto à coleta de imagens nas escolas que recebem estágio, cabe esclarecer que o Departamento de Ciências da Educação Física e Saúde da UFSJ já tem uma parceria firmada com as escolas conveniadas que prevê a autorização para realização da atividade junto à direção. Por fim, cabe ressaltar que todos os procedimentos adotados neste estudo foram apresentados e submetidos à avaliação do Comitê de Ética em Pesquisa da Faculdade de Ciências e Tecnologia da Universidade Estadual Paulista "Júlio de Mesquita Filho" (UNESP), Campus Presidente Prudente, sendo a pesquisa aprovada em janeiro de 2015.

\section{A SEMIÓTICA DE CHARLES S. PEIRCE: CONCEITOS FUNDAMENTAIS PARA A ARTICULAÇÃO ENTRE COMUNICAÇÃO E ESTÁGIO}

A semiótica peirceana é um original tratado de Lógica, alicerçado ao conceito de signo e de semiose. De forma ampla, signo é todo sinal que nos chega da realidade, que nos é dado a perceber, representando ou se colocando no lugar de alguma outra coisa que está fora dele. A palavra "educação física" ou "estágio", por exemplo, nos traz à mente uma ideia ou uma representação que nos remete ao que quer que seja que entendamos como tal. Também, o movimento e o corpo são signos e signos sempre são entes comunicantes, significantes, expressivos. 
Na definição de Peirce (2008), signo é qualquer coisa em processo de inter-relação, interação, interconexão com outra coisa, denominada seu objeto semiótico, de modo a expressar uma representação deste último para uma mente interpretadora - o que ocorre sempre na forma de um novo signo. Essa representação final sintetizada em um novo signo é denominada de interpretante. A definição de signo mais conhecida e disseminada do autor, diz: "um signo ou representamen é aquilo que, sob certo aspecto ou modo, representa algo para alguém" (Peirce, 2008, p. 46). Em termos conceituais, é importante percebermos que o objeto, o "algo representado", não é necessariamente uma "coisa" no sentido de um objeto material (o objeto semiótico pode ser um objeto físico, mas também um ato ou acontecimento, ou ainda sonhos, imaginações etc.) e o interpretante (que é responsável por engendrar o significado do signo por meio de outro signo) não se refere necessariamente a um agente humano (intérprete), mas refere-se a qualquer potencial interpretativo que um signo suscita a qualquer ente capaz de com ele estabelecer uma interconexão.

Já a ideia de semiose refere-se à ação do signo em seu processo de constituição, que tende à proliferação de novos e distintos signos, desencadeando, por conseguinte, infinitos processos de significação. Para Merrell (2012, p. 13), esses "processos e efeitos, no engendramento e interpretação de signos de todos os tipos e formas, quer por agentes humanos ou não humanos" Peirce denominou de semiose.

Assim, no fluxo da semiose, o potencial de representação de um signo é sempre falível ou parcial, pois, como alerta Peirce (2008, p. 47), "o Signo pode apenas representar o Objeto e referir-se a ele”, mas não é capaz de representá-lo em sua totalidade. Do contrário, seria ele próprio indistinguível do objeto. Ou seja, aquilo que está representado no signo não corresponde ao todo do objeto, mas apenas a uma parte ou aspecto dele. O signo é sempre incompleto em relação ao objeto.

Em relação a essa alteridade, Peirce formulou uma de suas classificações sígnicas mais conhecidas ${ }^{4}$, considerando que são três os tipos de propriedades qualidades, existência e convenções/leis - que dão fundamento aos signos e que, portanto, haveriam igualmente três tipos de relações que o signo pode ter com seu objeto: se o representamen estabelecer uma relação com o objeto por meio de uma qualidade que ambos têm em comum, o objeto lhe resguardará semelhança e será denominado de ícone. É o caso, por exemplo, de uma fotografia. Se o representamen estabelecer uma conexão existencial com o objeto, e não uma mera similaridade, assumindo uma função indicativa, esse signo é chamado de indice. O exemplo mais comumente citado é a fumaça (como índice do fogo), mas um professor que fala em um volume mais alto do que o habitual, de forma mais ríspida e com um semblante fechado é índice de um estado de raiva ou nervosismo (já que seu comportamento indicia tais sentimentos). Por fim, no caso de o representamen ser um signo geral,

4 As classificações sígnicas na obra peirceana foram inicialmente expostas em 1903, em uma publicação conhecida entre seus estudiosos como Syllabus. Nessa primeira classificação, Peirce apresentou um total de 10 classes de signos (entre os quais a classificação destacada por nós: ícone, índice e símbolos). Mas em alguns de seus manuscritos póstumos foram encontradas outras classificações de até 66 classes de signos. 
uma classe geral de objetos poderá com ele se correlacionar representando-o, e esse signo é chamado de símbolo. O exemplo mais conhecido são as palavras, que, para funcionarem como signos, precisam ser convencionadas dentro de uma comunidade linguística específica.

Outra classificação dos signos diz respeito a como os signos são interpretados, operando no nível dos interpretantes. O interpretante se refere ao terceiro elemento da tríade que constitui o signo, e dele Peirce extraiu três tipos básicos: o interpretante imediato, o interpretante dinâmico e o interpretante final.

$\mathrm{O}$ interpretante imediato refere-se a um potencial interpretativo inerente ao próprio signo. Assim, todo signo possui um interpretante interno, contido como potencial para uma mente intérprete. Se consideramos uma foto de uma aula de educação física, tal foto, mesmo sem ter sido observada por qualquer pessoa, contém um potencial para ser interpretada, de modo que quando o espectador a observar atualizará sua carga de significação.

Já o interpretante dinâmico trata-se do efeito particular que, efetivamente, o signo produz em um receptor. Esse interpretante gera/pode gerar três modos de afetação: emocional, energética e lógica. Quando um signo afeta seu intérprete por meio de uma simples qualidade de sentimento, seu efeito deverá ser de um interpretante emocional, trazendo os sentimentos ao primeiro plano. A dimensão icônica de uma música, de uma pintura ou de um vídeo nos afeta em nossos sentimentos. O segundo tipo de efeito ocasionado por um signo é o interpretante energético, que corresponde a uma ação (física ou mental), exigindo dispêndio de energia de alguma espécie. Os índices tendem a nos colocar em movimento, na busca de associar as relações causais a que dispõem seus intérpretes. O terceiro efeito de significação de um signo é denominado interpretante lógico, decorrente dos símbolos. É o entendimento geral determinado/indicado/sugerido pelo signo, ou "a apreensão intelectual do significado de um signo" (Johansen apud Santaella, 2000 , p. 80), conduzida por um hábito associativo e engendrador de possíveis mudanças de hábitos - dado que todo efeito interpretante lógico é transformativo e evolutivo no processo de interpretação.

Por fim, concebendo que todo processo interpretativo pode ir se estendendo rumo ao aumento de sua razoabilidade, Peirce concebeu em um nível abstrato, o interpretante final, "que se refere ao resultado interpretativo a que todo intérprete estaria destinado a chegar se os interpretantes dinâmicos do signo fossem levados até o seu limite último" (Santaella, 2002, p. 26). Trata-se, portanto, do limite de significação que um conceito ou ideia pode alcançar. Evidentemente, são raros os casos em que isso é possível - se é que podemos dizer que isso é realmente possível. Por isso, o interpretante final é um limite pensável, mas não inteiramente atingível. Sua função está em conduzir o pensamento rumo ao crescimento da razoabilidade do saber.

Com essas tríades (e outras não tratadas neste artigo), Peirce permite explorar os modos de ser dos signos, bem como o modo como eles operam em relação ao objeto semiótico e aos efeitos interpretantes que podem gerar, sem limitar estes últimos aos elementos lógicos, racionais, mas admitindo também seus elementos sensórios, emotivos, ativos e reativos como parte das relações interpretantes. 
O estágio pode ser pensado em suas bases semióticas como um processo pelo qual os professores em formação inicial interagem com sinais, indícios e convenções simbólicas que suscitam processos de significação não só em termos cognitivos, mas também e principalmente como meio de afetação das condutas, pois a lógica de produção e significação dos signos, segundo Peirce, não é apenas de ordem psicológico, ou racional, mas também sensível e criativa, fundada na comunicação e nas múltiplas linguagens (verbal, sonora, visual, imagética, digital).

Em nosso entendimento, é precisamente essa dimensão semiótica a raiz do processo de reflexão sobre as práticas pedagógicas. Isso porque o professor somente poderá se colocar em reflexão se for capaz de "ler" os problemas pedagógicos que emergem de sua aula e, para tal, é preciso que se reconheça como os signos estão a comunicar tais problemas. De modo que só é capaz de refletir aquele professor que for capaz de "ler" semioticamente os sinais/signos que emergem, circulam ou se mantêm latentes em uma aula.

Nesse quesito as contribuições peirceanas são profundamente promissoras, dado que o processo de interpretação decorrente da semiótica rompe com a habitual noção grega de que interpretação seja a relação entre as palavras e os pensamentos, ou entre os pensamentos e as coisas, de modo que o que quer que seja que ocorra no pensamento dá conta do que se passa no mundo. Ao contrário, em Peirce a interpretação não é um ato simplesmente mental, mas também um hábito de ação, uma resposta habitual e constante que o intérprete dá ao signo ou ao objeto. Ou seja, um signo pode ser interpretado em consequência de um hábito ou de uma disposição para a ação (Di Sarno, 2000). Portanto, de um ponto de vista semiótico, refletir sobre a prática significa não apenas interpretar de forma mental as situações pedagógicas analisadas, ou apenas construir pensamentos - signos mentais -, mas também agir e se predispor a agir são relações interpretantes, e não meramente resultantes de uma interpretação.

Interpretar, à luz das formulações peirceanas, significa estabelecer uma relação entre pensamento e ação/conduta. Essa correlação entre ação e interpretação foi apurada por Peirce em sua teoria da investigação ou perquirição (4), conhecida como pragmaticismo. O pragmaticismo considera que as ideias, os conceitos e "as palavras produzem efeitos físicos e que a essência de todo signo pode ser exibida numa influência em uma possível conduta" (CP 4.533)

Assim, na formação de professores, podemos inferir, tal como sugere Silva (2013, p. 22), que:

[...] ao deflagrar que a ação do signo estende-se para uma influência na conduta, ou para a geração de outros pensamentos, Peirce sugere que a semiose deve ser correlata a uma expansão do próprio conhecimento, ou melhor, a ação do signo exige a necessidade de investigar (pensar, perguntar, inquirir) sobre essa mesma ação.

5 Como convencionado, nos trabalhos sobre Peirce, utilizaremos a referência CP para sua obra Collected Papers aqui citada, sendo o primeiro número referente ao livro e o segundo ao parágrafo. 
Isso implica que o fio condutor de uma influência do pensamento na conduta é o mesmo que dirige a necessidade do questionamento. Nesses termos, a modificação dos signos torna-se consequência de uma ação de investigação/perquirição e da modificação da conduta. Não por acaso, Peirce (apud Ibri, 1992) concebia a aprendizagem como a inter-relação entre aquisição de conceitos e modificação na conduta ${ }^{6}$. Essas afirmações, a nosso ver, são chaves decisivas para o estudo da formação de professores e dos estágios supervisionados, atribuindo rumos mais concretos e, ao mesmo tempo, também mais complexos e mais profundos à formação docente nesse componente curricular.

Por exemplo, a questão da reflexão sobre a prática nos estágios pressupõe o entendimento do estágio como comunicação, o que até os dias atuais não nos parece explícito entre os autores que adotaram a perspectiva do que se convencionou chamar de professor reflexivo (Schön, 2000; Nóvoa, 1995). Afinal, a reflexão sobre a prática na formação de professores implica o entendimento das ações pedagógicas, incluído aí o estágio, como elementos comunicantes que se expressam por meio dos signos. Sendo assim, outro pressuposto que assumimos para o desenvolvimento desta tese é que a reflexão docente torna-se mais rica, consciente, crítica e autocrítica se antes o professor tiver desenvolvido uma capacidade de leitura semiótica das situações pedagógicas nas quais atua, no sentido de identificar os sinais que emanam de uma aula e que podem ser problematizados. Do contrário, como poderão os professores refletir sobre suas aulas, se não identificam, nelas, problemas latentes ou emergentes que afetem as relações pedagógicas propostas?

Reconhecemos, assim, que o paradigma do professor reflexivo não explicita a questão epistêmica de como a reflexão pode florescer no âmbito formativo. Bastariam formular problemas ou questões aos alunos? Bastariam autoquestionamentos? Como diz Peirce (1972), a formulação de hipóteses, premissas e inferências é uma faculdade aprendida, e não inata; sendo assim, o pressuposto para a reflexão é a capacidade de leitura semiótica, de decifrar os signos que emanam da realidade e engendrá-los em novas redes de significação.

Elaborar essa ideia e buscar "tirá-la do papel”, ou seja, operacionalizar uma perspectiva semiótica de estágio é um grande desafio para o campo da formação de professores ainda não explorado na literatura e pelas pesquisas da área.

\section{AS IMAGENS COMO SIGNOS DETONADORES: UM DIÁLOGO COM OS DADOS}

$\mathrm{Na}$ experiência de estágio analisada, pudemos constatar que a proposição de instituir um estágio supervisionado centrado na produção, socialização e análise de imagens fotográficas e audiovisuais foi, de fato, assumida como um compro-

6 O termo conduta na filosofia de Peirce não tem um caráter psicologizante e comportamentalista, ou seja, subjugado à alteração comportamental. O termo se refere à capacidade de, por meio das ideias, ampliar-se a razoabilidade estética, ética e lógica do pensamento, da ação e dos sentimentos. 
misso pelos PEFIs participantes do estudo, apesar de serem necessários estímulos e esforços pedagógicos permanentes para que a ética do compartilhamento e da colaboração fosse exercida no âmbito da rede social. Assim, foram publicadas na rede social utilizada pelo componente curricular 172 fotos e 16 fragmentos de vídeos das interlocuções escolares. Além dessas imagens, durante os 18 encontros presenciais na universidade, mais 6 fragmentos de vídeos que não circularam nas redes sociais foram trazidos ao debate espontaneamente pelos PEFIs para serem analisados pública e coletivamente. Com todo esse material, além de outras imagens produzidas pelos PEFIs, foram criados oito videodocumentários das experiências que cada um dos grupos de PEFIs vivenciou nas escolas.

Os números evidenciam que havia mais fotos publicadas, embora a maior parte delas $(68,6 \%)$ não contivesse comentários analíticos, sendo meramente ilustrativas, ao passo que com os vídeos a proporção foi invertida e $75 \%$ deles geraram comentários e avaliações do grupo.

Além do levantamento quantitativo sobre as fotos e vídeos produzidos pelos PEFIs, questionamo-nos sobre que tipo de análise os PEFIs faziam desse material. O que observavam, destacavam e discutiam nas imagens produzidas por eles próprios? Em grande parte, havia um olhar sobre a própria conduta, portanto para as questões didáticas, tais como a forma como agiam em determinadas situações, a organização das aulas, o efeito emocional causado por determinada atividade e/ou conteúdo sobre os alunos. Ao início do semestre, as análises eram mais simples e destacavam as próprias qualidades/características pessoais:

Nataly: Eu sou muito nervosa, fico nervosa quando meus alunos estão fazendo outra coisa.

João: Eu vejo que sou muito brincalhão e isto atrapalha também.

Ao olharem para as imagens com foco nos alunos, no entanto, os PEFIs destacavam principalmente os efeitos emocionais que tomavam conta da aula ou então a ação corporal dos alunos como elemento comunicante:

Kelly: Tem que perceber se os alunos estão gostando da atividade.

Alessandro: A aula é boa quando flui bem, quando os alunos ficam felizes.

Cristina: Os alunos iam saindo. Não estava funcionando.

Nadir: a aula foi a maior confusão. Eles [alunos] foram saindo.

Inicialmente não eram feitas análises mais aprofundadas, no sentido de questionar por que as aulas ou determinada atividade "funcionavam" ou "não funcionavam" (termos utilizados com frequência pelos PEFIs). Ou, ainda, por que os alunos gostaram ou não gostaram? Sem o exercício da dúvida, o raciocínio abdutivo ficava comprometido, não havendo hipóteses que ajudassem a orientar uma reordenação das aulas que, na avaliação dos PEFI, não iam bem, ou mesmo para compreender quais fatores auxiliavam os PEFIs a obter êxito em suas aulas. 
Apesar dessas análises mais simples, em termos de avaliação das condutas pessoais como docentes, do êxito de determinadas aulas ou atividades ter sido o imperativo durante todo o estágio, em especial na rede social, pudemos notar que houve um crescente desenvolvimento da capacidade analítica da maior parte dos PEFIs ao longo do semestre em relação à análise das imagens. Vejamos duas análises que indicam essa melhora: a empreendida pelos PEFIs na primeira foto postada por eles e, na sequência, a análise de um dos vídeos apresentados como trabalho final da disciplina.

A primeira fotografia (Figura 1) publicada pelos PEFIs mobilizou cerca de sete comentários da turma, dois dos quais aparecem a seguir:

Charplin: Eu imagino que o garoto pela sua postura está em um confronto contra ele mesmo, pode ser que ele não queria estar ali naquela aula ou alguma coisa ocorreu ali naquele momento para ele ficar assim.

Nilton: Ao usar o cinza como escala de cor senti uma angústia. Ainda mais com esse menino de cócoras. A foto aponta para um aluno que não parece confortável em estar ali, ou com algum problema, cansaço; Penso que o ensinar da educação física não pode ser monocromático. Será que conseguiremos mudar essa tonalidade? (grifo nosso)

A partir da foto destacada, os PEFIs fizeram inicialmente uma primeira rodada de comentários com teor mais especulativo e apelaram para uma lógica

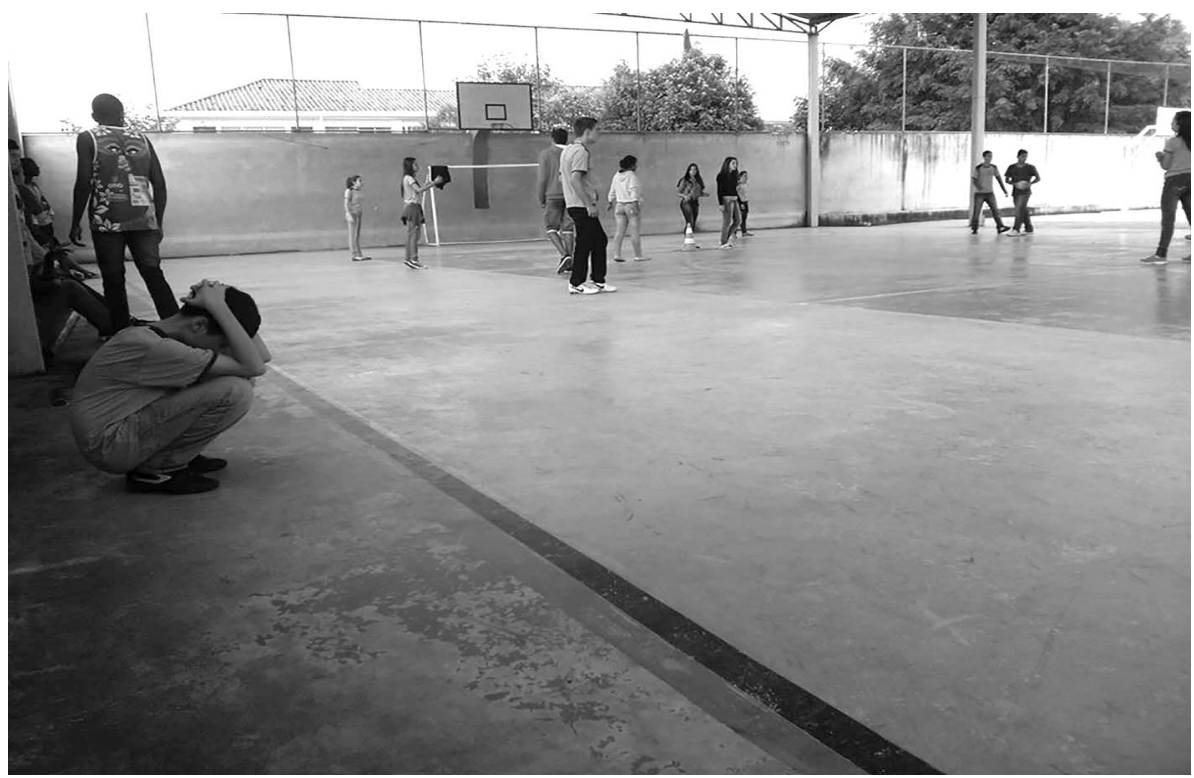

Figura 1 - Primeira fotografia postada na rede social pelos professores em formação inicial.

Fonte: acervo pessoal do pesquisador. 
abdutiva, levantando livremente hipóteses ou abstrações avaliativas. Esse tipo de "análise" mais livre por parte dos PEFIs era mais imediatista e, apesar de atentos a certas denotações sígnicas presentes nas fotos, os participantes já iniciavam o processo de análise a partir das considerações intuitivas mais imediatas, ou de relações interpretantes individuais, sem uma maior atenção à complexidade das relações sígnicas, desconsiderando, algumas vezes, os aspectos envolvidos nos fundamentos dos signos, ou na relação estabelecida entre a foto e o objeto denotado. Por vezes, alguns comentários impunham sobre o signo imagético uma interpretação já pronta, do tipo "a foto revela uma aula que não fluiu bem" (PEFI Cândida, Diário de Campo).

Observamos, no entanto, que mesmo esse tipo de leitura mais imediatista não era, em muitos casos, arbitrário, contendo capacidade para produzir associações e interpretações diferenciadas que foram além de outras mais simples. É o que exemplifica o comentário do PEFI Nilton, que apontou ter sido provocado a pensar pela foto que "o ensinar da educação física não pode ser monocromático", em uma analogia entre o monocromatismo presente na foto e o modo de ser de uma aula sem vida, sem cor, sem alegria, apta a produzir sensações de desinteresse nos estudantes do ensino médio, do mesmo modo que a foto lhe transmitia certa "angústia". Mesmo sem ter realizado uma leitura metodologicamente sistematizada, o PEFI conseguiu produzir uma interpretação bastante diferenciada dos demais colegas.

Apesar disso, para que nos aprofundássemos em termos de uma lógica de análise, os PEFIs foram estimulados a se atentar às análises subsequentes, aos preceitos advindos da gramática especulativa de Peirce, ou seja, de sua classificação dos signos e das relações lógicas que os signos carregam e desencadeiam em termos de interpretantes - especialmente a partir das sugestões didáticas para leitura/análise de imagens de Santaella (2001;2012). Para a autora, em uma análise de fotos/vídeos devem-se seguir três passos metodológicos:

1. abrir-se ao fundamento do signo, ou seja, "auscultar os fenômenos. Dar-lhes a chance de se mostrar” (Santaella, 2001, p. 30). Nesta etapa, três tipos de olhares são destacados:

1a. a disponibilidade contemplativa para ater-se às qualidades dos signos - cores, texturas, formas, volumes, movimentos etc.;

1b. a observação situacional, a situação comunicativa em que a imagem se coloca - perceber sua condição concreta de existência, suas singularidades, todos os traços que lhes são particulares;

1c. a observação generalizante - que busca identificar classes gerais que estão contidas no próprio signo, ou seja, extrair do signo aquilo que ele tem em comum com outros signos;

2. explorar o poder representativo dos signos - a que o signo se refere, se aplica, denota ou representa? Aqui se exploram mais características icônicas, indiciais e simbólica dos signos;

3. estabelecer relações interpretativas - é o momento de tornar explícitos os efeitos que os signos despertam em nós, levando em conta os fundamentos e os objetos dos signos, cuidando para não impor sobre os signos uma interpretação já pronta, extraída de um repertório prévio. 
Em síntese, trata-se de uma análise que considera as características internas do signo analisado, suas referências (seu conteúdo) e as interpretações que enseja. Já ao final do semestre letivo, nas análises dos vídeos produzidos como trabalho final da disciplina, foi possível observar que uma parcela expressiva dos estudantes (aproximadamente 22 dos 30 PEFIs matriculados) havia melhorado na qualidade das análises pedagógicas que faziam. Vejamos alguns comentários:

Kelly: Eu queria falar. Anotei aqui qual o argumento do vídeo de vocês. Pra mim é que o estágio de vocês foi tudo tranquilo. Mas durante o semestre a gente viu que não foi bem assim. Repare que todas as cenas são dos alunos sorrindo, empolgados com a aula. Isto significa o que? Pra mim, é que foi tudo mil maravilhas. As músicas todas alegres. Que emoção criou? [...] Que foi festivo. Mas e as cenas de dificuldade? Os conflitos das fotos?

Nataly: Tem uma cena ali que vocês colocaram a música de rock pesado. Qual a sensação que criou? Eu fiquei com sensação de que foi pesado, pauleira! Foi isto mesmo? Porque a imagem estava jogando contra o que se estava mostrando. A ideia das imagens era de muita alegria na aula. Eu queria entender isto. [....] Outra coisa: O PEFI tá usando apito. Já pensou no que significa o apito pra Educação Física?

Cândida: Eu observo que nesta cena, a PEFI está com toda expressão corporal de insegurança. Olha lá: Mãos na cabeça, a sobrancelha alta, a testa tá até enrugada, o olho arregalado. Já os alunos estão de costas pra ela. É como se ela estivesse sendo ignorada e o corpo dela tá dizendo que algo ali tá preocupante.

Além de observarmos uma melhora qualitativa no teor das "leituras" e análises das imagens produzidas pelos PEFIs, buscamos interpretar quais foram as imagens e os vídeos que mais mobilizaram os acadêmicos a perquirir, analisar e discutir. Em outras palavras, o que era mais interessante para os PEFIs nas imagens? Averiguamos que as imagens que mais produziram comentários, análises e debates foram aquelas que flagravam situações/acontecimentos inusitados, quase sempre de conflitos e dificuldades vivenciados pelos PEFIs nas interlocuções pedagógicas.

Vejamos alguns exemplos. A primeira foto postada pelos PEFIs, destacada anteriormente, segundo seus autores, foi responsável por captar de forma inusitada o garoto em situação de exclusão, o que provocou o grupo a buscar estratégias de inclusão daquele estudante que indicava ter desinteresse pelas aulas de educação física. Segundo o relato de uma PEFI pertencente ao grupo que produziu a foto, aquela imagem teria provocado o grupo a visualizar aspectos presentes na aula que a observação sem os registros imagéticos não havia lhes proporcionado, conforme descreve o registro a seguir:

Hoje, pelos corredores, Mara me encontra e diz que o seu grupo já está selecionando fotos para serem publicadas no Facebook da turma. O que me chamou a atenção foi seu comentário de que, ao final da aula, [...] ela e os demais membros 
do grupo se reuniram e, ao observarem as fotos registradas, encontraram situações que somente foram capazes de perceber por causa de algumas fotos acidentais. Viram/perceberam uma situação de sofrimento e exclusão de um aluno somente na foto. $\mathrm{O}$ fato não foi percebido durante a aula. (Diário de Campo)

Outro exemplo. Logo na segunda aula em que se discutia a entrada dos PEFI em campo, a estagiária Penélope postou no grupo da rede social uma cena em vídeo de conflito entre ela e seus alunos (Figura 2).

A cena, previamente editada, mostrava um jogo de queimada modificado, em que uma estudante "queima" a colega com muita força. A PEFI intervém, pede a bola e solicita uma conversa com seus alunos, que, na sequência, se mostram desinteressados em se reunir para ouvir ou conversar com a PEFI e reclamam sobre a interrupção do jogo. Enquanto os estudantes se reuniam ao centro da quadra, a PEFI, já irritada, começa a dizer, exaltada, que considerava que aquela a aula só havia ficado boa no final, que os alunos perderam muito tempo com conflitos pequenos e que não seguiam as regras, nem buscavam soluções para os problemas que foram colocados na aula - a saber, como jogar com mais de uma bola ao mesmo tempo. Alguns alunos tentam argumentar com a professora, falando ao mesmo tempo que ela e em tom igualmente ríspido. Um número pequeno de alunos fica ao centro da quadra escutando e discutindo com a professora, enquanto outra parte sai da quadra.

As imagens produzidas pelos PEFIs, principalmente por meio do audiovisual, captaram acontecimentos inusitados das aulas, momentos em que o planejamento foi totalmente arrebatado por algum tipo de contingência (exemplo da Figura 2). $\mathrm{E}$ foi precisamente nesses momentos de contingência de uma aula que as crenças

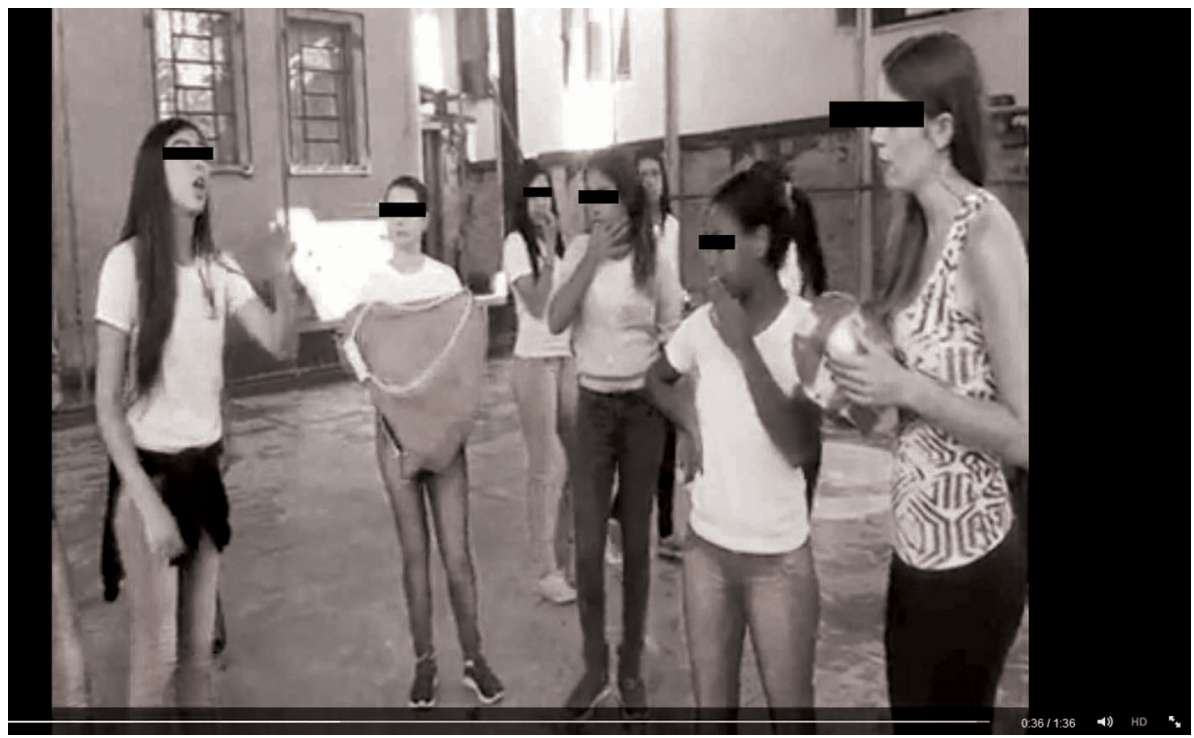

Figura 2 - Cena de conflito escolar em vídeo dos professores em formação inicial.

Fonte: acervo pessoal do pesquisador. 
pedagógicas passaram a ser tensionadas e postas em dúvida. A imagem, assim, se constituiu em um signo capaz de colocar em evidência as dúvidas dos PEFIs. Mas, sobretudo, permitia tornar público o processo de significação daquelas cenas e, portanto, mais amplo e favorável à autocorreção.

Tomando o vídeo de Penélope como exemplo, nosso argumento fica mais evidente. A PEFI em questão postou o vídeo destacado, alegando sentir-se frustrada com os alunos da turma, que não se interessavam pelas aulas de educação física e que não sabiam conviver respeitosamente nem entre si, nem com a PEFI, já que não a escutavam. Em seu texto na internet, após narrar um pouco como havia sido a aula, a PEFI concluiu dizendo:

Penélope: Desde o início os alunos não estavam respeitando as regras, deixando o jogo muito confuso e sem sentido. No decorrer da aula foram adicionadas mais regras para que eles pensassem em novas estratégias, porém eles começaram a reclamar muito, pois só queriam jogar do jeito deles. Dessa forma, só no final da aula eles participaram de forma coerente no jogo, fazendo com que este fluísse e eles se divertissem. Como estava no final da aula eu tive que parar a atividade, neste momento eles começaram a reclamar pois estavam gostando. Tentei discutir o motivo deles não terem aproveitado a aula desde o começo, nesta hora fiquei muito irritada e frustrada, pois os alunos me deram as costas me ignorando enquanto falava e tentava construir uma solução junto deles. (grifos nossos)

Aqui, portanto, Penélope apresentava aos colegas PEFIs e ao professor-pesquisador a relação interpretante que estabeleceu a partir da situação pedagógica por ela vivida e questionada. A sua aula agora passava a ser uma "aula-signo", bem como suas condutas pedagógicas nela encarnadas. A aula e a performance da PEFI, encarnadas em um vídeo-representamen, operavam como objetos semióticos (a face expressiva de um signo) de uma certa interlocução escolar. Estavam, assim, sinalizando, indicando, apresentando uma situação de aula como seu objeto-semiótico, uma realidade tornada acessível a qualquer intérprete que com ela entrasse em contato, por meio do signo imagético. Os textos e as falas de Penélope também se constituíam agora em signos aptos a representar os pensamentos/interpretações que a PEFI fazia de sua aula.

A autora do vídeo reafirmava que ela teria parado a aula ao final para perguntar (grifo nosso) aos alunos por que somente naquele momento a aula havia dado certo. E ratificou: "todo mundo me olhou com a maior cara feia e saiu andando, saindo da aula". O problema apresentado no relato da PEFI consistia na falta de respeito dos estudantes entre si e com ela, o que inviabilizava o diálogo. Mas outros problemas foram visualizados nas imagens pelos demais PEFI, que indicaram não ter havido uma atitude dialógica por parte de Penélope. Ao contrário do que ela narrava, não se via no vídeo uma tentativa de "construir solução junto deles [dos alunos]". O vídeo revelava uma fala de mão única, ou como disse a PEFI Kátia, em avaliação que foi corroborada pelos demais PEFIs, "foi uma bronca" (PEFI Kátia, Diário de Campo). Outros PEFIs também questionaram o momento em que a PEFI optou por interromper a aula e o tom ríspido de sua fala, dando razão à insatisfação dos 
alunos, já que a PEFI havia paralisado a aula quando os conflitos já haviam sido resolvidos internamente entre os alunos e tudo corria bem.

Ao mesmo tempo em que os colegas de estágio supervisionado questionavam as condutas da PEFI em questão, sugestões também eram apresentadas, tais como: rever a atitude autoritária no momento das discussões, permitindo aos alunos se expressarem, mesmo que isso demandasse muito tempo de aula; fazer a explicação de atividades novas na sala de aula, antes de os alunos se deslocarem até a quadra, onde há certa dispersão que favorece os mal-entendidos, gerando maiores conflitos entre os alunos; não fazer muitas interrupções nas aulas para dialogar sobre todos os aspectos que irritam a professora, mas focar-se nos conflitos que realmente inviabilizam a aula e o aprendizado dos alunos, e interromper somente quando estritamente necessário, reservando um momento ao início e ao final das aulas para tratar dos conflitos.

O que se passou com a produção dessa cena audiovisual e sua publicação exemplifica o potencial formativo que as imagens dos PEFIs traziam às aulas, gerando diferentes pontos de vista sobre uma dada situação pedagógica, o que permitia uma compreensão ampliada dos problemas pedagógicos vivenciados, bem como de algumas interpretações individuais formuladas pelos autores das imagens, que, por vezes, não atentavam ao que as imagens revelavam, ou denotavam; ao contrário, tentavam utilizar as imagens para reafirmarem uma ideia prévia que tinham das situações vividas, ou seja, de suas crenças.

Ao longo do semestre letivo, o grupo de Penélope seguiu trazendo imagens das aulas seguintes e postando na internet relatos de suas aulas, dos novos conflitos que foram surgindo. Após um mês de estágio, por meio das sugestões dos colegas, do professor-pesquisador e pelo empenho pessoal que empreenderam, o grupo de Penélope conseguiu melhoras com as turmas que vinham tendo dificuldade de participação e de comunicação, além de problemas disciplinares.

Exemplos como esses, que se assemelharam a outras situações em que os vídeos e fotos captaram situações inusitadas e/ou problemáticas, permitiram constatar que a utilização das imagens fotográficas e dos audiovisuais no estágio pode auxiliar a formação dos PEFIs, dado que sua condição de registro viabiliza um (re)encontro com situações vividas anteriormente (em outro espaço/tempo) de modo objetivado, materializado e encarnado em um registro perene, que transforma o vivido em uma alteridade, "um outro" com o qual é possível confrontar-se desde um ponto de vista "externo". Como explicam Santaella e Nöth (2012), por meio da fotografia e do vídeo, temos uma "colisão ótica" com o real traduzida em um novo signo imagético. Tal colisão é fruto de um recorte estabelecido pelo olhar e que, em verdade, trata-se também de uma nova realidade, diversa, mas ao mesmo totalmente interdependente/inseparável da realidade primeira captada. Logo, o registro de um dado acontecimento em um suporte fotográfico (estático) ou audiovisual (imagem em movimento) nos permite um reencontro com algo já vivido/observado por alguém em outro espaço/tempo e que, materializado em uma imagem (agora digital), pode ser revisitado, revisto, reexaminado quantas vezes se quiser. Isso implicou que as imagens das interlocuções escolares foram "signos detonadores" de novas semioses. 
As imagens, com seu aparato afetivo, emocional, conflitivo-existencial e com suas representações simbólicas, tinham o poder de "disparar", de mobilizar, de colocar em atividade o exercício de interpretar, de estar apto a sentir, agir e pensar os efeitos que as imagens evocavam, denotavam, sugeriam, indicavam, representavam. Interpretar, para Peirce (1974), é aperceber-se do fluxo semiósico, das interconexões, das inter-relações, das interações que decorrem do estar-em-contato-com a realidade mediada pelos signos.

As imagens produzidas pelos PEFIs eram, então, signos detonadores de semiose porque, como sustentam muitos estudiosos das imagens (Barthes, 1984; Santaella e Nöth, 2012), suas mensagens são polissêmicas e mais abertas do que aquelas dos textos. Sendo assim, as imagens são signos que convidam à interpretabilidade. Não por acaso, a linguagem verbal torna-se essencial para fazer as significações que emanam das imagens ao campo do argumento, do raciocínio lógico-formal. A dimensão indexical das imagens indicia que, para além da realidade icônica que elas comportam, algo ficou de fora de seu enquadramento. Suas bordas revelam seus limites, ao mesmo tempo em que sinalizam para a existência de algo mais na realidade delimitada por sua espacialidade própria. Assim, tão logo encontram intérpretes dispostos a entrar em contato com seu potencial significativo, processos de semiose são desencadeados.

As fotografias e os vídeos dos PEFIs, por evidenciarem aspectos de suas aulas que muitas vezes não eram percebidos no momento mesmo da intervenção, abriam a oportunidade para que pudessem emergir relações interpretantes/semioses diferenciadas daquelas experimentadas no momento exato da vivência de uma aula, que normalmente são marcados por sentimentos imediatos (interpretante emocional) e por (re)ações que visam a atender às demandas mais imediatas de controle das condutas (interpretante energético). Essas novas relações elevaram a significação ao nível dos interpretantes lógicos, campo no qual há formulação intelectual de generalizações, de conceitos e de novos hábitos, levando à aprendizagem.

Com as imagens, as tensões dos conflitos vividos nas escolas foram trazidas para dentro da aula de estágio supervisionado. Os PEFIs que não estavam vivenciando tais conflitos imediatamente se mostravam impactados emocionalmente com as imagens e, por conseguinte, formulavam e manifestavam suas relações interpretantes, que quase sempre começavam pela esfera emocional, como revela a fala a seguir:

Nataly: A gente se sente [vendo o vídeo do colega] incomodado, dava uma agonia.... Tá louco! É como se estivesse lá, e todo mundo sabe que vai viver uma coisa assim. Aí você já vai ficando preparado...vendo a aula do outro. A gente nem tava lá, como PEFI, como professora, mas eu imagino o que elas passaram. Eu já fico com raiva daqui!

Dessa afetação primeira, emocional, os PEFIs se colocam imediatamente a agir, a falar com o colega do lado, a verbalizar suas hipóteses, seus julgamentos. Era comum nas aulas de estágio, no momento da apresentação de alguma foto ou de vídeo das aulas vividas pelos PEFIs, que um "murmurar" coletivo emergisse. Em termos semióticos, podemos ler tal agitação como mais um efeito interpretante, 
ou seja, um interpretante energético. Essa agitação, no entanto, não se tratava de uma ação de desinteresse, denotando desrespeito pelas narrativas apresentadas. Pelo contrário, o impacto emocional das imagens (de conflitos ou surpresa) convertia-se em interpretante energético manifesto no pensamento-em-ação, na ação de verbalizar a aflição imediata, de questionar como cada um agiria, ou em julgar as ações que viam nas cenas retratadas, ou ainda em apontar que também estavam vivendo ou já haviam vivido experiência semelhante.

O impacto emocional das imagens comovia os PEFIs, a ponto de os mobilizar para uma atitude de exposição argumentativa. As imagens promoviam os diálogos, as interações frequentes em sala de aula a respeito das dificuldades dos grupos. Os colegas apontavam diferentes pontos de vista, com críticas e sugestões em relação às interlocuções pedagógicas por eles desenvolvidas, o que permitia o desencadeamento de interpretantes lógicos, de relações interpretantes generalizantes, lógico-dedutivas e racionais, sugerindo avaliações mais críticas por parte dos PEFIs. Afinal, como escreve Santaella (2000, p. 89), a crítica, na trama semiósica, não brota "apenas sob o efeito dos movimentos lógicos do próprio pensamento, mas sob efeito da insistência do pensamento que não cessa de aparecer sob novos ângulos". E, para que novos ângulos do pensamento se manifestem e se imprimam ao signo, é fundamental a multiplicidade de linguagens e de "pontos de vista", ou, se quisermos, de "jogos interpretativos" diferenciados.

O confronto com as "leituras" das imagens e das situações pedagógicas foi fundamental para elevar o nível das discussões ao campo dos argumentos. Os PEFIs entrevistados também reconheceram esse aspecto como fundamental:

Alice: Pra mim o principal neste estágio foram os conflitos. Mas também a troca de ideias, a interferência dos outros colegas. Eram dez cabeças pensando junto, e a gente se revia, porque, por exemplo, eu tinha achado que minha aula tinha sido horrorosa, mas á́ outro via ali coisas que eu não tinha visto e mudava meu ponto de vista. Cada um agregava um pouco, alguns vendo coisas diferentes, outros trazendo teorias, textos... A coisa ia crescendo, e a gente daí ia pensando diferente.

Nesse sentido, consideramos a elucidação e o enfrentamento dos conflitos apresentados pelas imagens e pelos relatos orais dos PEFIs como os aspectos mais importantes para que o estágio supervisionado promovesse modificação das condutas docentes dos PEFIs e, portanto, aprendizagem, sobretudo na explicitação de pontos de vista discordantes, questionadores ou mesmo retificadores. Somente no tensionamento das significações mais imediatas é que a dúvida podia se apresentar e o processo de semiose se expandia, gerando novas relações interpretantes. Apenas por meio de uma dúvida real é que as crenças pedagógicas dos PEFIs eram efetivamente colocadas em xeque, abrindo caminho para que novas associações interpretantes se efetivassem. Inúmeras foram as situações em que o elemento de conflito se apresentou por meio do compartilhamento das imagens dos PEFIs e ganhou novos contornos no processo de análise coletiva das imagens e dos fatos sugeridos nesses signos. É o que exemplifica o caso do vídeo divulgado por Penélope. 
A produção e o compartilhamento de fotos e vídeos das aulas dos PEFIs permitiram que o componente curricular estágio supervisionado se transformasse em um verdadeiro "jogo de interpretantes". Ora os PEFIs podiam ver a si mesmo e se autoavaliarem; ora podiam partilhar suas imagens e, com isso, fazer não apenas sua autoavaliação, mas também contar com a interpretação dos demais sobre a cena exibida. E, por fim, podiam também, eventualmente, assistir às imagens de si próprios avaliando-se mutuamente, a partir de imagens produzidas pelo professor-pesquisador a respeito de suas aulas.

O argumento aqui não é novo no campo da educação (embora pouco "colocado em prática"), mas compõe um dos pilares do que entendemos por uma perspectiva semiótica de estágio. A esse respeito, Paulo Freire, em 1983, já revelava a Sérgio Guimarães, em uma série de diálogos sobre educação e meios de comunicação, a importância dos professores se reverem em tape, e que ele próprio, algumas vezes, se autoavaliou a partir de registros de aulas suas (Freire e Guimarães, 2011). Mas, se o argumento não é exatamente novo, as condições em que a tecnologia se encontra atualmente, mais precisamente quanto à produção e à socialização de imagens fotográficas e audiovisuais, são muito mais avançadas em relação às das décadas de 1970 e 1980. O ato de fotografar e filmar tornou-se uma quase compulsão pela alimentação de compartilhamento de informações no mundo digital, de modo que utilizar a fotografia e o audiovisual agora, mais do que nunca, passa a ser meio não apenas de aperceber-se do objeto apreendido na imagem, mas também para uma compreensão ampliada do próprio ato de produzir imagens em um mundo em que uma das formas principais de narrativa se dá pelos meios e produtos imagéticos.

Outro aspecto relevante que investigamos com os PEFIs foi que as imagens produziam/detonavam relações interpretantes com mais intensidade que os relatos orais das interlocuções pedagógicas, não apenas porque (de)flagravam a surpresa e o inusitado, mas porque superavam os limites de eloquência dos PEFIs. Para os PEFIs entrevistados, os estágios anteriores por eles vivenciados, centrados na linguagem verbal (relatos orais e escritos), foram comparativamente menos mobilizadores da participação, em termos de dialogar sobre as experiências de ensino dos colegas e da colaboração da turma no enfrentamento dos problemas pedagógicos por eles vividos.

De acordo com a semiótica de Peirce, a comunicação é em si semiósica, ou seja, busca a interconexão, a inter-relação e a interação dos signos na direção da produção de novos signos diversos e mais complexos (Merrell, 2002), conduzindo a um aumento da "razoabilidade concreta" das ideias, das ações, dos sentimentos (Santaella, 2004). Sendo assim, as diferentes linguagens (oral, escrita, imagética, sonora), por serem constituídas por diferentes tipos de signos (a palavra, por exemplo, é fundamentalmente simbólica, ao passo que as imagens são mais icônicas e indiciais), desencadeiam diferentes efeitos interpretantes. Os relatos orais e os planos de aula, na opinião dos PEFIs entrevistados, não davam conta de apresentar uma certa vivacidade a respeito da aula narrada, pois os PEFIs não se consideravam eloquentes, ou seja, capazes de falar ou escrever de maneira envolvente, eficaz para deleitar e comover os demais. Além disso, os relatos orais que não transmitiam vivacidade, verossimilhança com o contexto das aulas, ou que não desafiavam o 
estado de crença (pedagógica) dos PEFIs, produzindo dúvidas reais, não lhes eram convidativos ao engajamento para discutir ou refletir sobre a experiência. Por esses motivos, a tradução das experiências de estágio tão somente por intermédio da linguagem verbal tem sido limitadora das possibilidades de semiose que se abrem quando outras linguagens são trazidas ao universo dos estágios. Operar com outras linguagens, em especial a imagética, parece permitir aos PEFIs novas formas de expressão (criativa) da realidade vivida nos estágios que não excluem o verbal do processo, mas que complementam essa linguagem, ou até motivam a verbalização como forma de ampliação do processo de significação.

Constatamos, assim, que o exercício de leitura de imagens modificou a leitura de aula e algumas condutas dos PEFIs, especialmente em dois aspectos:

1. maior atenção ao olhar para as situações pedagógicas vivenciadas; e

2. consolidação de uma atitude coletiva e colaborativa para planejar e analisar as interlocuções pedagógicas escolares.

Essas novas condutas foram registradas pelo professor-pesquisador em seu diário de campo, bem como foram confirmadas nos grupos de discussão realizados. Algumas falas dos PEFIs ilustram isso:

Livina: Mas não foi só a gente que falava. Eu aprendi que as imagens falam, que uma aula fala demais...Há muita comunicação silenciosa em tudo.

Wilson: Mudou a forma de ver as aulas. Antes a gente só dava a aula e pronto. Agora já é automático: a gente vai dando aula e ao mesmo tempo vai "filmando" tudo, se atentando aos detalhes, ao que está fora da aula, ao que estou transmitindo... É o que você falava de atenção no olhar.

Mara: Nós não percebemos os signos que nós somos em uma aula, o que estamos representando para o aluno. O professor põe o foco apenas no aluno, mas não se atenta para o fato de que também estamos sendo interpretados.

Nadir: Acho que finalmente a gente aprendeu que na escola não dá pra ser sozinho. Pra ser bom professor tem que trabalhar junto, com toda a escola mesmo, sabe? Falta os professores falarem mais entre si [...] todo mundo se ajuda e todo mundo sai ganhando.

No que se refere à aquisição de novos hábitos ou tendências de ação, observamos que o uso repetitivo das imagens e das redes sociais em sala de aula pelo professor-pesquisador repercutiu na apropriação dessas tecnologias no fazer pedagógico dos PEFIs. Um dado importante é que, dos oito grupos formados durante as aulas de estágio, cinco integraram alguma atividade com uso das imagens e/ou uso das redes sociais da internet em suas interlocuções pedagógicas junto aos alunos do ensino médio, inclusive com estratégias didáticas similares às utilizadas pelo professor-pesquisador, mesmo sem terem cursado na universidade alguma disciplina específica a respeito dessa temática, ou mesmo sem terem sidos solicitados ou estimulados (de forma explícita, ao menos) a tal. 


\section{CONSIDERAÇÕES FINAIS}

Pudemos constatar que todos os PEFIs, ao final do semestre, consideraram como fundamental, para sua formação como professores, o ato de ver-se e rever-se nas telas de forma coletiva e reflexiva. Assim, se dissemos que as imagens são uma possibilidade de retificar a percepção, de um ponto de vista semiótico isto é a condição mesma para uma mudança da conduta. A possibilidade de um professor em formação observar a si mesmo em uma situação pedagógica de modo objetivado, exercendo um olhar externo sobre sua própria atividade, demonstra ser um relevante aspecto para alcançar uma mudança de hábito docente. $\mathrm{Na}$ teoria peirceana, a mudança de hábito está relacionada à surpresa, ao acaso. A surpresa tem o poder de romper com a associação de ideias e, desse modo, tem força para modificar comportamentos. Outro fator destacado por Peirce (1974) para a mudança de hábito são os "atos de imaginação" contidos em uma autoanálise formada com a ajuda de exercícios prévios da vontade, ou seja, o pensamento analítico e criativo.

Sendo assim, concordamos que as imagens dos estágios foram signos propícios para registrar o acaso e promover a surpresa, estimularam as exposições verbais e o esforço analítico para interpretá-las e favoreceram o estímulo imaginativo, sendo, portanto, fundamentais a uma perspectiva semiótica de estágio e, por conseguinte, para a mudança de crenças e hábitos docentes.

Para consolidarmos uma perspectiva semiótica de estágio foi necessário assumir a fotografia e o audiovisual como linguagens capazes de ampliar os processos de significação a respeito das interlocuções escolares e da formação docente. Entendemos que a produção de relações interpretantes, decorrente da ação sígnica, pode ser ampliada tanto quanto maior e mais diversificada for a capacidade de uma mente ser afetada de múltiplas maneiras. Porque a semiose, como uma ordenação lógica dos processos de continuidade do pensamento, não se organiza exclusivamente por meio de signos simbólicos, como as palavras e as linguagens verbais. Antes, "outros tipos de signos, além dos símbolos, intervêm e são necessários à condução do pensamento e das linguagens. A mistura sígnica é parte integrante do pensamento e de todas as manifestações de linguagem" (Santaella, 2000, p. 90). Assim, operar com signos imagéticos e audiovisuais, além dos signos verbais, na formação de professores (em tempos de uma cultura altamente imagética, como é o caso da cultura digital) é necessário não apenas para atualizar os cursos de formação. É, antes de tudo, apostar na constituição de uma abertura aos processos interpretativos e inferenciais mais amplos e qualitativamente diferenciados no que diz respeito à experiência de constituir-se como professor.

Por fim, o estudo permitiu ratificarmos a ideia de que a premissa ontológica e teleológica dos estágios é a comunicação. Que o estágio é, fundamentalmente, comunicação, entendendo esse termo em sua acepção comunal, ou seja, a comunicação como uma experiência compartilhada e de compartilhamento, e seus agentes como participantes inter-relacionados com/para a atividade de criação/recriação e de produção de sentido. Assim, o estágio avançou de simples local de aplicação de teorias predefinidas, ou de lugar de transmissão de informação, para um espaço 
de comunhão, de compartilhamento de emoções e experiências, de múltiplas afetações sígnicas, de permanente reconhecimento e engendramento de novos e distintos signos acerca da docência, portanto, como experiência gregária.

\section{REFERÊNCIAS}

Barthes, R. A câmara clara: nota sobre a fotografia. Tradução de. Júlio Castañon Guimarães. 9. impressão. Rio de Janeiro: Editora Nova Fronteira, 1984.

BetTi, M. “Imagens em ação”: uma pesquisa-ação sobre o uso de matérias televisivas em programas de educação física do ensino fundamental e médio. Revista Movimento, Porto Alegre, v. 12, n. 2, p. 95-120, mai.-ago. 2006.

Di SARno, I. C. O ofício de interpretar: objeto enquanto aparência e realidade à luz da filosofia de Peirce. 2000. 105f. Dissertação (Mestrado) - Programa de Pós-Graduação em Filosofia, Pontifícia Universidade Católica de São Paulo, São Paulo, 2000.

Elliot, J. El cambio educativo desde la investigacion-acción. Madrid: Morata, 1993.

. Recolocando a pesquisa-ação em seu lugar original e próprio. In: Geraldi, C. M. G.; Fiorentini, D.; Pereira, E. M. A. (Org.). Cartografias do trabalho docente. Campinas: Mercado da Letras, 1998. p. 137-152.

Franco, M. A. S. Pedagogia da pesquisa-ação. Educação e Pesquisa, São Paulo, v. 31, n. 3, p. 483-502, set.-dez. 2005.

Freire, P.; Guimarães, S. Educar com a mídia: novos diálogos sobre educação. São Paulo: Paz e Terra, 2011.

Ibri, I. A. Kósmos noetós: a arquitetura metafísica de Charles S. Peirce. São Paulo: Perspectiva, 1992.

Merrell, F. A semiótica de Charles S. Peirce hoje. Ijuí: Unijuí, 2012.

. Quão "reais" os signos podem se tornar? In: LeÃo, L. (Org.). Interlab: labirintos do pensamento contemporâneo. São Paulo: Iluminarias, 2002. p. 255-269.

Morgan, D. Focus group as qualitative research. London: Sage Publications, 1997.

NóvoA, A. Formação de Professores e Formação Docente. In: NóvoA, A. (Coord.). Os professores e sua formação. 2. ed. Lisboa: D. Quixote, 1995. p. 13-33.

Peirce, C. S. Escritos coligidos. São Paulo: Abril Cultural, 1974.

. Ilustrações da lógica da ciência. trad. Renato Rodrigues Kinouchi. Aparecida, SP: Ideias \& Letras, 2008.

. Collected papers of Charles Sanders Peirce. ed. by Charles Hartshorne and Paul Weiss. Vols.1-6. Cambridge, Massachusetts: Harvard University Press, 1931-35.1958. Pimenta, S. G.; Ghedin, E. (Org.). Professor reflexivo no Brasil: gênese e crítica de um conceito. 4. ed. São Paulo: Cortez, 2006.

Santaella, L. A teoria geral dos signos: como as linguagens significam as coisas. São Paulo: Cengage Learning, 2000.

Hacker, 2001.

. Comunicação e pesquisa: projetos para mestrado e doutorado. São Paulo: 
Santaella, L. Semiótica aplicada. São Paulo: Cengage Learning, 2002. . Leitura de imagens. São Paulo: Melhoramentos, 2012. . Nöтн, W. Imagem: cognição, semiótica, mídia. São Paulo: Iluminuras, 2012. . Contribuições do pragmatismo de Peirce para o avanço do conhecimento. Revista de Filosofia, Curitiba, v. 16 n.18, p.75-86, jan.-jun.2004. Disponível em: <http://www2. pucpr.br/reol/index.php/RF?dd1=90\&dd99=pdf.>. Acesso em: 19 mai. 2014.

Silva, F. A. Q. Modificação do acontecimento" como semiose: a relação entre meios e sociedade em uma perspectiva semiótica. 2013.226f. Dissertação (Mestrado) - Programa de Pós-Graduação em Comunicação, Universidade de Brasília, Brasília, 2013.

Stenhouse, L. La investigacion como base de la enseñanza. 2. ed. Madrid: Morata, 1993. TRIPP, D. Pesquisa-ação: uma introdução metodológica. Educação e Pesquisa, São Paulo, v. 31, n. 3, p. 443-466, set.-dez. 2005.

\section{SOBRE OS AUTORES}

Diego de Sousa Mendes é doutor em educação pela Universidade Estadual Paulista "Júlio de Mesquita Filho" (UNESP). Professor da Universidade Federal de São João del-Rei (UFSJ).

E-mail: diegomendes@ufsj.edu.br

Mauro Betti é doutor em educação pela Universidade Estadual de Campinas (UNICAMP). Professor da Universidade Estadual Paulista "Júlio de Mesquita Filho" (UNESP).

E-mail: maurobettiunesp@gmail.com

Recebido em 30 de novembro de 2016 Aprovado em 10 de abril de 2017 